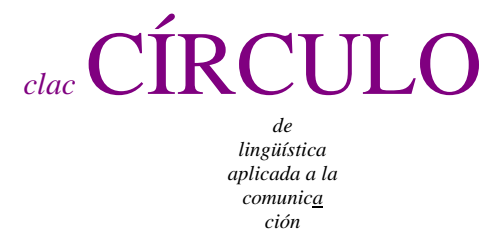

$67 / 2015$

\title{
CRITICAL APPROACHES TO DISCOURSE ANALYSIS ACROSS DISCIPLINES (CADAAD)
}

http://www.cadaadjournal.com

Critical Approaches to Discourse Analysis across Disciplines is a peer-reviewed electronic journal intended to provide a publishing platform for critical discourse research.

$C A D A A D$ aims to promote all approaches to critical discourse research within the humanities and social sciences. The journal therefore welcomes papers from Critical Discourse Analysis as well as other 'critical' strands of Applied Linguistics, Communication Studies, Media Studies, Discursive Psychology, Sociology and Political Science.

We publish papers which investigate, from a 'critical' perspective, contemporary discourse and genres in social, political, public and professional communication. In this context, we are especially interested in publishing papers which highlight, develop and apply new theoretical and methodological frameworks for critical discourse research or which assess established methods and assumptions, including Cognitive Linguistics, Cognitive Pragmatics and Corpus Linguistics.

Critical approaches to discourse analysis across disciplines (CADAAD).

Círculo de Lingüística Aplicada a la Comunicación 67, 372-373.

http://www.ucm.es/info/circulo/no67/cadaad.pdf

http://revistas.ucm.es/index.php/CLAC

http://dx.doi.org/10.5209/CLAC.53493 
Editorial Board

General Editor: Charlotte Taylor (University of Sussex)

Assistant Editor: Monika Kopytowska (University of Lodz)

Copy Editor: Susanne Kopf (Lancaster University)

Volume 8.12016

Weining Ji and Wei Wang

THE 45 YEARS' EVOLUTION OF A GENRE: COMMODIFICATION OF THE UNIVERSITY TEXTBOOK PREFACE IN CHINA

Victoria Wirth-Koliba

THE DIVERSE AND DYNAMIC WORLD OF 'US' AND 'THEM' IN POLITICAL DISCOURSE

Nicholas Close Subtirelu and Shakthidhar Reddy Gopavaram

CROWDSOURCING CRITICAL DISCOURSE ANALYSING: USING AMAZON'S MECHANICAL TURK TO EXPLORE READERS' UPTAKE OF COMMENTS ABOUT LANGUAGE ON RateMyProfessors.com

Eun-Young Julia Kim

PERSUASIVE STRATEGIES IN A CHAUVINISTIC RELIGIOUS DISCOURSE: THE CASE OF WOMEN'S ORDINATION

Franco Zappettini

THE CONSTRUCTION OF TRANSNATIONAL IDENTITIES IN THE NARRATIVES OF A EUROPEAN CIVIC ORGANISATION

Published: September 23, 2016

Updated: October 21, 2106 